\title{
台風の強大化に伴う伊勢湾湾奥部の 高潮・高波による汇濫危険度の評価 RISK ASSESSMENT OF INUNDATION INDUCED BY STORM SURGE AND HIGH WAVE UNDER INTENSIFICATION OF TYPHOON IN INNERMOST REGION OF ISE BAY
}

\author{
川崎浩司 1 ・ 丹羽竜也 2 \\ Koji KAWASAKI and Tatsuya NIWA \\ 1正会員 博(工) 名古屋大学准教授 大学院工学研究科社会基盤工学専攻 \\ （广464-8603 名古屋市千種区不老町C1-3(651)） \\ 2正会員 修(工) パシフィックコンサルタンツ(株) 国土保全技術本部 港湾部 \\ （テ206-0034 東京都多摩市関戸1-8-5）
}

\begin{abstract}
The purpose of this study is to numerically examine the inundation characteristics induced by storm surge and high wave under the intensification of typhoon due to the global warming in innermost region of Ise Bay and assess the inundation risk. The numerical model employed in this study is comprised of the Myers-based typhoon model, a depth-averaged flow model with a one-way nesting technique, the wave model SWAN and an inundation model with a CIP method. The numerical results showed that the damage under virtual huge typhoon is as severe as or even more than one caused by Ise Bay typhoon in 1959. The risk assessment of the possible inundation were also discussed by making use of six inundation risk indices and an integrated risk index based on the numerical results.
\end{abstract}

Key Words : Risk assessment,Storm surge, High wave, Inundation, Typhoon, Ise Bay

\section{1.はじめに}

今後，進行するとみられる地球温暖化によって， 台風が強大化し，沿岸部では高潮・高波災害の増大

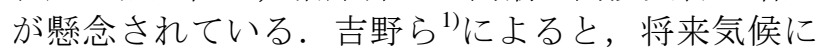
おいて最大強度の台風が上陸した場合，名古屋港に おける高潮は，満潮と重なり，さらに温暖化による 海面上昇を考慮すると, 最大で $8.07 \mathrm{~m}$ に達するとさ れている。このように強大化した台風が発生した場 合，既存の海岸施設では防御できない大災害になる 可能性があり，対策を講じることが急務である。し かしながら，防災・減災対策のための十分な検討に 至っていないのが現状である.

本研究では, 将来発生しうる超大型台風が伊勢湾 に来襲した場合を想定し，川崎ら ${ }^{2}$ が開発した高潮 時の陸域汇濫に及ぼす高波の影響を考慮することが できる高潮・高波氾濫モデルを用いて数值計算を行 い，伊勢湾湾奥部における高潮氾濫状況について検 討寸る. さらに, 浸水深, 氾濫流速, 氾濫流到達時 間などをはじめとし，多面的な視点から高潮・高波 による汇濫危険度指標を提案・議論することで，伊 勢湾湾奥部の高潮・高波氾濫に対寸る危険度を総合 的に評価する.

\section{2. 高潮・高波氾濫モデルの概要}

本研究では，先に述べたように川崎ら ${ }^{2)}$ が開発し た高波の影響を考慮可能な高潮・高波汇濫モデルを 用いて，超大型台風を想定した数值計算を実施した， ここでは，同モデルの概要について示す.

高潮・高波氾濫モデルは，Myers による台風モデ ル，one-way ネスティング手法を導入した単層流動 モデル，第 3 世代波浪推算モデル SWAN

(Simulating WAves Nearshore)，Yabe and Aoki ${ }^{3)}$ が 開発した高精度な移流計算が可能な CIP

(Constrained Interpolation Profile) 法に基づく氾濫 モデルから構成されている。 さらに，高潮氾濫時に おいて不規則に変動する高波の影響を，平均的な水 面上昇としてみなし，モデル化している.

計算の流れとしては，まず，台風経路・中心気圧 を用いて台風モデルから気象場を計算し, 得られた 気象場を基にSWANを用いて波浪場を推算する。つ いで，単層流動モデルと汇濫モデルに，気象場と波 浪場の情報を取り込み，高潮・高波汇濫計算を行っ ている。なお，モデルの詳細については，川崎ら を参照されたい。また，同モデルの妥当性・有用性 については，川崎ら ${ }^{2)} に よ る 1959$ 年の伊勢湾台風を 対象とした再現計算によって，既に実証済みである。 


\section{3. 台風の強大化に伴う伊勢湾湾奥部の高潮 汇濫特性}

\section{（1）計算条件}

計算領域は，図-1に示すように外洋を含むArea1, 伊勢湾を含むArea2〜Area4，伊勢湾湾奥部のArea5 に分割して設定した。各計算領域の設定条件を表-1 に示す。なお，氾濫計算を行うArea5は国土地理院

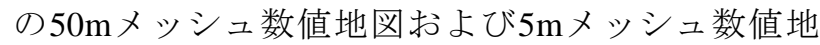
図をもとに作成した.

Area5における陸上でのマニングの粗度係数は,

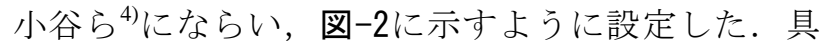
体的には，住宅の密集している名古屋市などの地域 では粗度係数 $n$ を 0.08 とし, その他の住宅の中密集 地帯では $n=0.06$, 工業地帯では $n=0.04$, 建物があま りみられない地域では $n=0.02$ とした。

氾濫計算においては, 最小浸水深を $0.1 \mathrm{~m}$ に設定 し，それ以下の水深のときに流速を0とした。 また， 初期流量は 0 とし, 静水状態とした。 なお，水位の 初期条件については，計算の安定性を考慮し，計算 領域全体に気圧低下による吸い上げ効果による潮位 偏差のみ与えた。

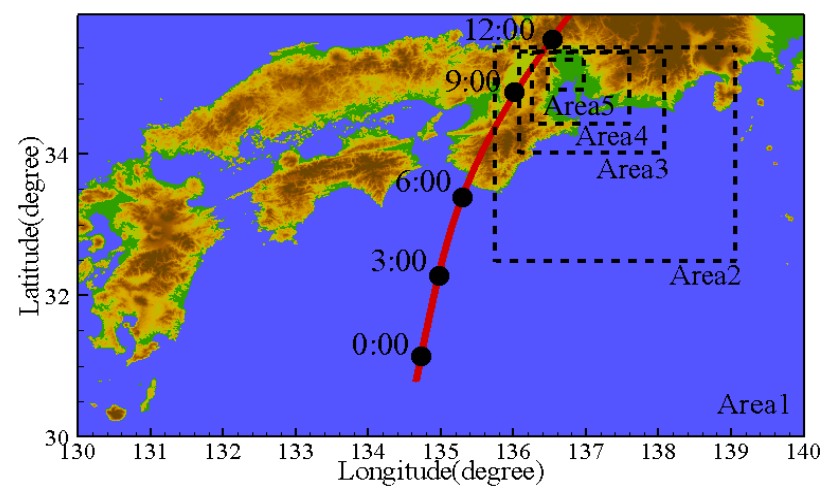

図-1 計算領域および台風経路

表-1 計算領域の設定条件

\begin{tabular}{c|c|c|c|c|c}
\hline & Area1 & Area2 & Area3 & Area4 & Area5 \\
\hline $\begin{array}{c}\text { 格子間隔 } \\
\text { (degree) }\end{array}$ & $3 / 40$ & $1 / 40$ & $1 / 120$ & $1 / 360$ & $1 / 1080$ \\
\hline 解像度 & $130 \times 80$ & $135 \times 126$ & $243 \times 171$ & $360 \times 288$ & $402 \times 300$ \\
\hline 時間間隔(s) & 24.3 & 8.1 & 2.7 & 0.9 & 0.3 \\
\hline
\end{tabular}

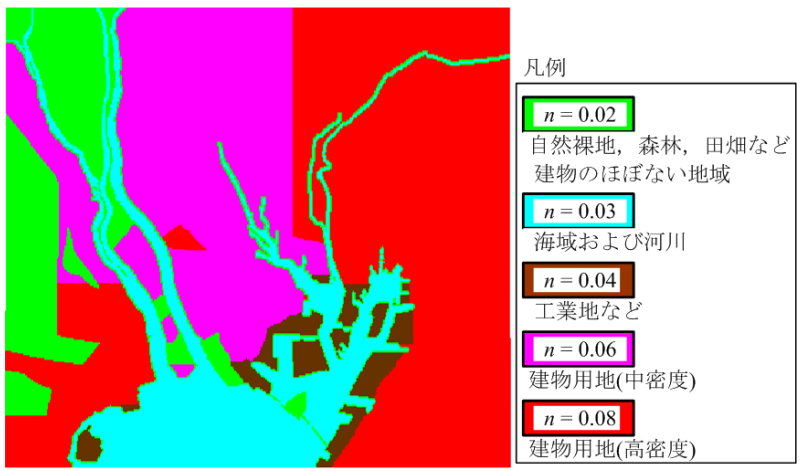

図-2＼cjkstart粗度係数の設定(Area5)

\section{（2）海岸護岸・河川堤防の設定条件}

伊勢湾台風来襲後, 高潮防波堤の建設や海岸護岸 の復旧など, 伊勢湾湾奥部では数多くの高潮対策が 進められた。図-3に, 伊勢湾台風計算時（伊勢湾台 風当時）と仮想大型台風計算時（現在）における海 岸，河川堤防の設定条件をそれぞれ示す，両図をみ ると，現在では，これまでの高潮対策により伊勢湾 台風当時より強固な護岸・堤防が建設され, 埋立な どにより当時と異なる地形が形成されていることが わかる。例えば, 名古屋港では, 高さT.P.+6.5mの 高潮防波堤が建設され, さらに埋立地が新設されて いる。.また，木曽川，長良川の河口部周辺において も，T.P.+8.2m堤防が建設されている。なお，本 研究では, 日光川水閘門が開いている状態を仮定し, 計算を行った。

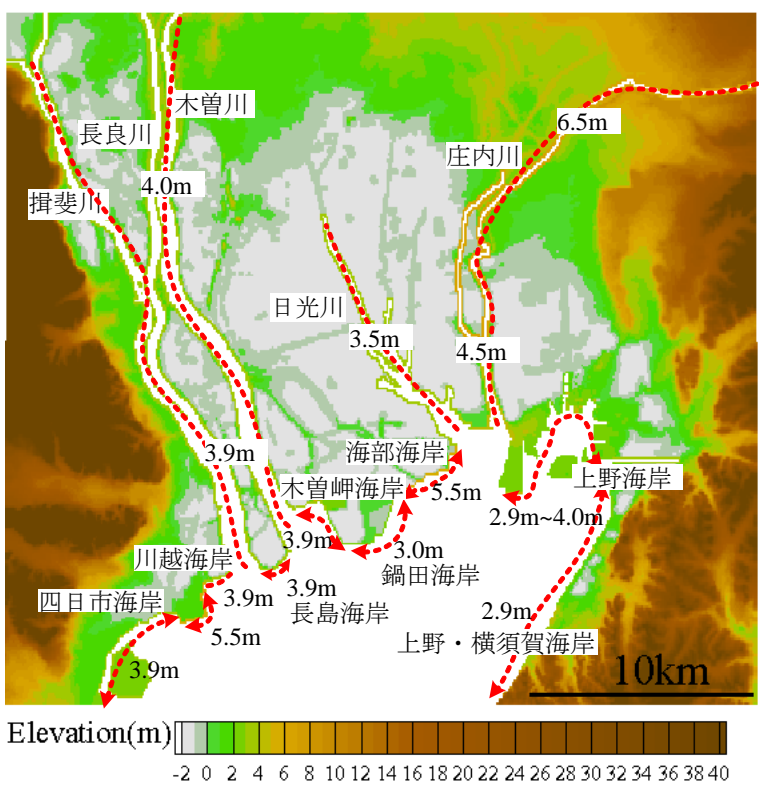

(a) 伊勢湾台風時

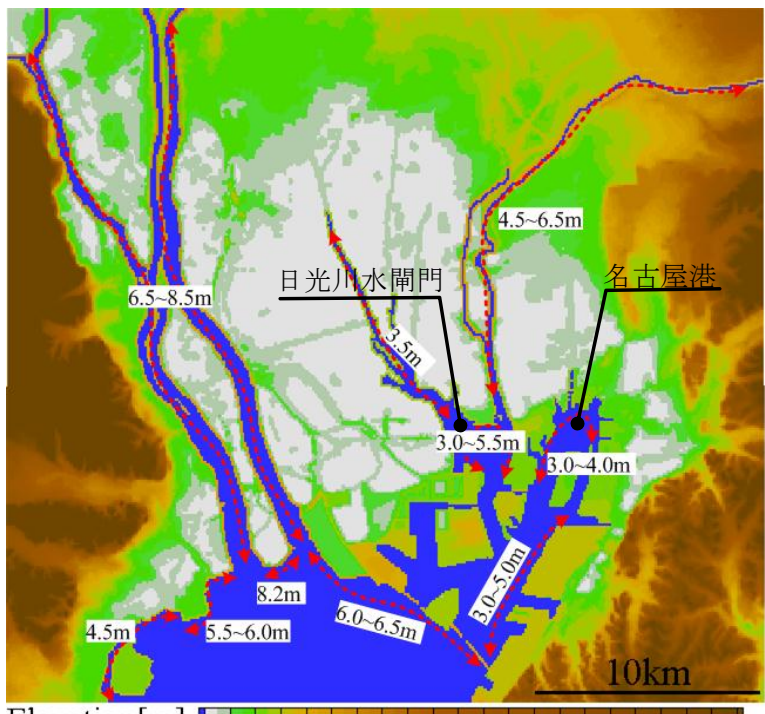

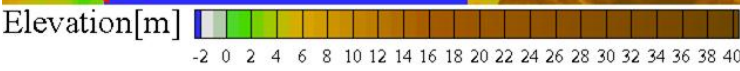
(b) 仮想大型台風計算時

図-3 海岸護岸・河川堤防の設定条件 


\section{（3）仮想大型台風の設定}

吉野ら ${ }^{1)}$ は, 将来気候において発生しうる最大規 模の台風を, CMIP3マルチ気候モデルデータの高度 成長シナリオSRES A1Bの2099年9月のデータより 推定している。 その結果, 将来発生しうる最大規模 台風の名古屋港上陸時の中心気圧は約 $910 \mathrm{hPa}$ に達す るとされている.

本研究では, 台風上陸時に名古屋港において計測 される気圧が，吉野ら ${ }^{1)}$ が推定した将来発生しうる 最大規模の台風と同程度となるように仮想大型台風 を設定した。具体的には，仮想大型台風の経路は， 図-1に示寸ように伊勢湾台風と同一とし，中心気圧 が，図-4に示すように，上陸時に約 $910 \mathrm{hPa}$ 程度とな るように伊勢湾台風と比べ50hPa低く設定した。 そ の結果, 台風モデルによって計算される名古屋港で の最大風速は, 図-4に示すように, 伊勢湾台風と比 較して約 $10 \mathrm{~m} / \mathrm{s}$ 上昇した。 また，伊勢湾湾奥部にお いて最大規模の氾濫が発生する場合を想定して数值 計算を行った。具体的には，天文潮位は，朔望平均 満潮位T.P.+1.22mに, 将来予想される海面上昇量を 加え, 一定值で与えた。すなわち, IPCCの高度成 長シナリオSRES A1Bによれば，今世紀末には地球 温暖化に伴い, 全球平均で $0.35 \mathrm{~m}$ 海面が上昇すると 予測していることから, 天文潮位はT.P. $+1.57 \mathrm{~m}$ と設 定した.

\section{（4）伊勢湾湾奥部の高潮および汇濫特性}

図-5に，仮想大型台風と伊勢湾台風による名古屋 港の潮位の時系列変化を比較したものを示寸，同図 より, 仮想大型台風においては, 名古屋港での最大 潮位は約 $6.4 \mathrm{~m}$ に達しており, 伊勢湾台風と比べ約 $2.4 \mathrm{~m}$ 高いことがわかる. 伊勢湾台風当時の潮位は T.P.+0.37 $\mathrm{m}$ 程度であるのに対し, 本計算では潮位を T.P. $+1.57 \mathrm{~m}$ としている. 従って, $1.2 \mathrm{~m}$ が天文潮位に

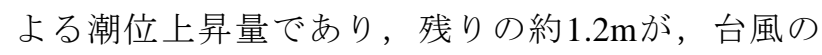
強大化に伴う高潮への影響と地形の変化による影響 と考えられる．さらに，仮想大型台風では，伊勢湾 台風時の最大潮位より高い潮位が約 2 時間半もの間 続いており，湾奥部での大規模な汇濫が予想される． また, 仮想大型台風による高潮は, 伊勢湾台風に比 べ15分ほど遅れて最大潮位を記録している。これは， 伊勢湾台風以後に建設された高潮防波堤に起因寸る と推察される.

湾奥部で生じる最大浸水深分布を, 伊勢湾台風時 と仮想大型台風時で比較して, 図-6に示す. なお, 同図中の点線は，伊勢湾台風時の氾濫域を示してい る. 同図より, ゼロメートル地帯（図-3(b)中の灰 色部分）は浸水深が大きく, 特に危険な地域である ことがわかる。また，仮想大型台風による氾濫域は， 伊勢湾台風時の汇濫域とほぼ同等の範囲に広がって いる。したがって, 伊勢湾台風来襲後, 図-3(b)の ように高潮防波堤の建設や海岸護岸の復旧といった 高潮・高波対策が実施されたにもかかわらず，台風 の強大化により，伊勢湾台風と同等の大規模な汇濫 が生じることが判明した。

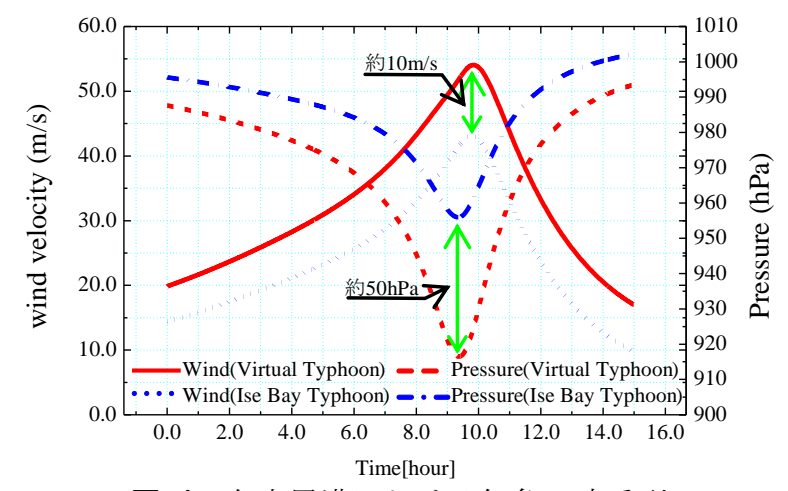

図-4 名古屋港における気象の時系列 （仮想大型台風と伊勢湾台風の比較 : 計算值)

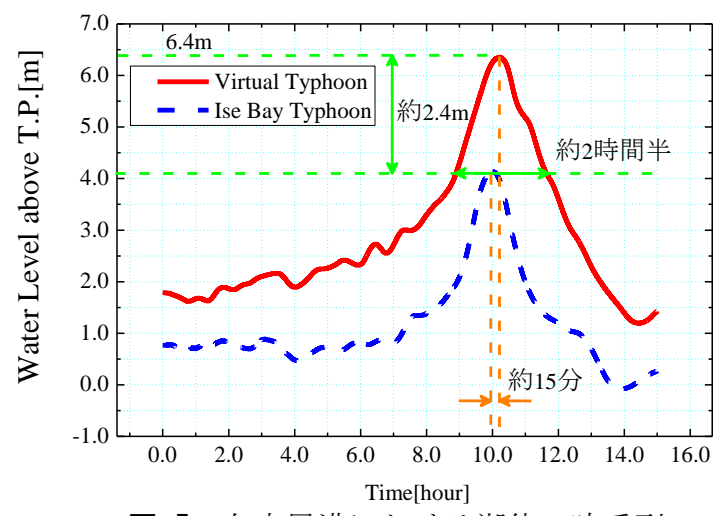

図-5 名古屋港における潮位の時系列 （仮想大型台風と伊勢湾台風の比較 : 計算值)

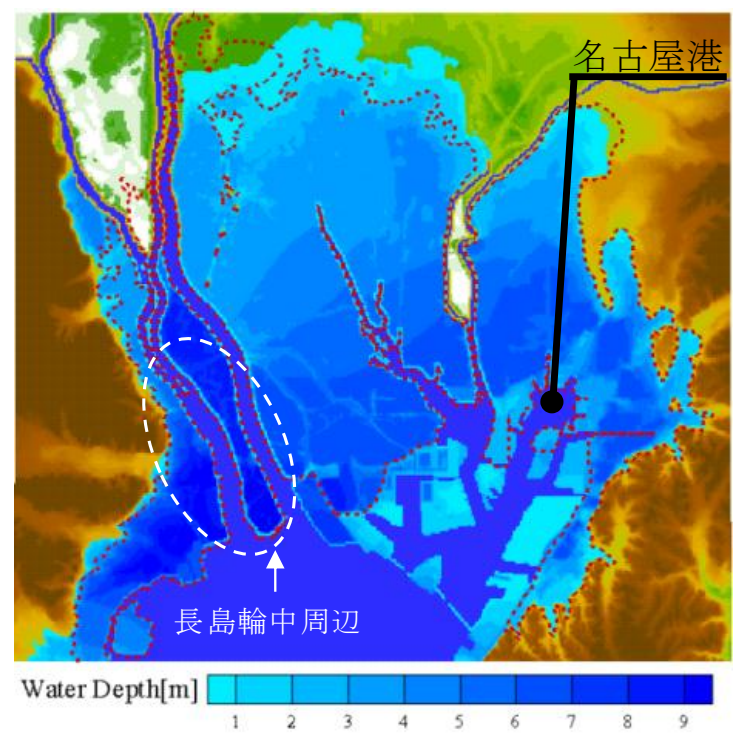

図-6 伊勢湾湾奥部の氾濫域 (赤点線 : 伊勢湾台風時の計算結果)

\section{4. 伊勢湾湾奥部の汇濫危険度評価}

先に示したように, 将来発生しうる強大な台風に よる甚大な高潮・高波災害を防ぐためには，早急な 対策が必要である。しかしながら，限られた予算で 海岸護岸や河川堤防などのハード面の対策を全面的 に見直すことは非常に困難であり，ハード対策につ いては効率化を図る必要がある。加えて, 事前に氾 
濫の危険性を住民に周知させるといったソフト対策 も必要不可欠である.

以上の高潮防災の観点から，想定される高潮・高 波氾濫の挙動を把握し, 適切に危険度を評価寸るこ とが重要である。そこで, 本研究では, 浸水深, 汇 濫流速, 歩行困難度, 氾濫流到達時間, 家屋被害, 車・コンテナの流出といった観点から6種の氾濫危 険度指標を設定し, さらに, これらの指標を用いて 各汇濫危険度を検討するとともに, 総合的な氾濫危 険度についても評価を行う。

\section{（1）高潮・高波による氾濫危険度指標の設定} a）浸水深に基づく氾濫危険度指標

高潮・高波汇濫が発生した場合，その危険性を最 もわかりや寸く住民に示寸指標は，水深であると考 えられる，国土交通省が公表している浸水想定区域 図作成マニュアル ${ }^{5}$ によれば，浸水した場合に想定 される水深（浸水深）については, 浸水深のランク 別の等深線をもって表示することとされている．た だし, 浸水深のランク付けは地域ごとの浸水の危険 度などを考慮して設定する必要がある。本研究では, 国や地方公共団体が公表している標準的な浸水深の ランク分けにならい，表-2に示すとおりに浸水深に 基づく氾濫危険度指標を設定した。

\section{b）汇濫流速に基づく氾濫危険度指標}

氾濫発生時には，徒歩による避難が原則とされる。 そのため, 汇濫流が到達する前に避難を完了させる ことが望ましい。しかし，万一避難が遅れた場合な ど, 氾濫流が到達後の浸水状態においても避難する 場合がありえる.よって, 汇濫流の流速により避難 が困難となることを示し, 浸水前の早期避難を促す 必要がある。ここでは，建設省河川局 ${ }^{6}$ による危険 度のランク分けを参考に，表-3のように設定した。

\section{c）歩行困難度に基づく氾濫危険度指標}

歩行による避難が困難であることをより明確に示 寸指標として歩行困難度が挙げられる.浸水してい る場合の歩行避難時には, 主に水深と流速の関係か ら危険度が決定されるといわれている。例えば，実 際の避難行動に近い状況を想定した水中歩行実験7) によると, 成人男性の場合, 水深が膝程度 (40〜 $50 \mathrm{~cm} ）$ のとには，流速がある程度あったとして も，ゆっくりではあるが安定して歩ける. 水深が股 下程度 $(80 \mathrm{~cm})$ のときには，大きく影響を受け歩 きづらくなる。これらの結果がまとめられたものが 図-7である。 また，末次 ${ }^{8}$ は，浸水している場合の 歩行避難時には, 主に水深と流速の関係から危険度 が決定されることから，表-4に示すように，避難の 可能性を表現している. 本研究では, 同表をもとに 歩行困難度に基づく氾濫危険度指標を設定した。同 汇濫危険度指標は, 歩行による避難が可能な場合に 氾濫危険度 1 , 困難な場合に氾濫危険度 2 , 不可能な 場合に氾濫危険度3とした。

\section{d）汇濫流到達時間に基づく汇濫危険度指標}

避難基準や避難行動を考慮する上で，氾濫流の到 達時間は有力な情報となる。氾濫流の到達が早いほ
ど，避難行動などの対策が困難となる。到達時間は， 計算領域内の陸域で浸水が発生した時間を0とし， その時点から計測した. 汇濫流到達時間に基づく汇 濫危険度指標は，表-5に示すとおりに設定した。

\section{e）家屋被害に基づく汇濫危険度指標}

避難場所への距離が長く, 避難が困難である場合 や，自宅の2階などの高いところで汇濫が治まるの を待つ場合など, 避難を行えない, もしくは行わな いことがある．そのため，家屋被害に基づく氾濫危 険度指標を示寸ことで, 家屋が氾濫によって破壊さ れる危険性を知らせ，避難を促寸必要がある。また， 災害に強い街づくりといった観点からも重要な項目

表-2 浸水深に基づく氾濫危険度指標

\begin{tabular}{c|c|c}
\hline $\begin{array}{c}\text { 氾濫 } \\
\text { 危険度 }\end{array}$ & 浸水深 & 浸水の目安 \\
\hline 1 & $0.5 \mathrm{~m}$ 未満 & 大人の膝までつかる程度 \\
\hline 2 & $0.5 \mathrm{~m}$ 以上 $1.0 \mathrm{~m}$ 未満 & 大人の腰までつかる程度 \\
\hline 3 & $1.0 \mathrm{~m}$ 以上 $2.0 \mathrm{~m}$ 未満 & 1 階の軒下まで浸水する程度 \\
\hline 4 & $2.0 \mathrm{~m}$ 以上 $5.5 \mathrm{~m}$ 未満 & 2 階の軒下まで浸水する程度 \\
\hline 5 & $5.5 \mathrm{~m}$ 以上 $7.5 \mathrm{~m}$ 未満 & 3 階の軒下まで浸水する程度 \\
\hline 6 & $7.5 \mathrm{~m}$ 以上 & 3 階の軒下以上が浸水する程度 \\
\hline
\end{tabular}

表-3 氾濫流速に基づく汇濫危険度指標

\begin{tabular}{c|c|c}
\hline $\begin{array}{c}\text { 氾濫 } \\
\text { 危険度 }\end{array}$ & 流速 & 避難の可能性 \\
\hline 1 & $0.5 \mathrm{~m} / \mathrm{s}$ 未満 & 水深が腰以下のとき避難可能 \\
\hline 2 & $0.5 \mathrm{~m} / \mathrm{s}$ 以上 $1.5 \mathrm{~m} / \mathrm{s}$ 未満 & 水深が膝以下のとき避難可能 \\
\hline 3 & $1.5 \mathrm{~m} / \mathrm{s}$ 以上 & 安全な避難は困難 \\
\hline
\end{tabular}

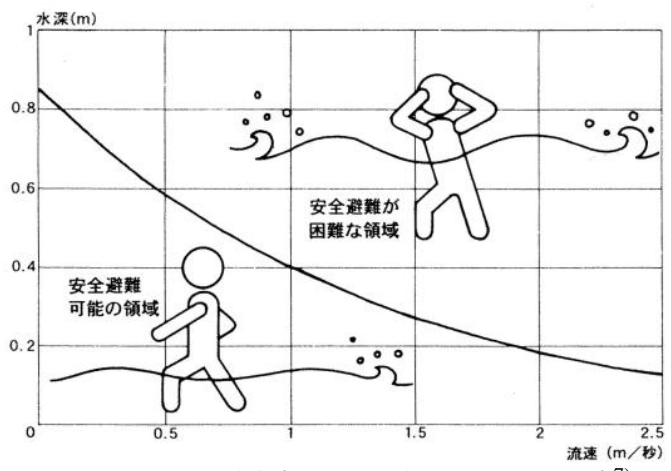

図-7 洪水避難時に水中歩行できる領域7)

表-4 流速と水深の関係による徒歩での避難可能性

\begin{tabular}{c|c|c|c}
\hline 浸水深 $h$ & $1.0 \mathrm{~m} \leqq h$ & $0.5 \mathrm{~m} \leqq h<1.0 \mathrm{~m}$ & $h<0.5 \mathrm{~m}$ \\
\hline $1.5 \mathrm{~m} / \mathrm{s} \leqq U$ & 不可能 & 不可能 & 困難 \\
\hline $0.5 \mathrm{~m} / \mathrm{s} \leqq U<1.5 \mathrm{~m} / \mathrm{s}$ & 不可能 & 困難 & 可能 \\
\hline$U<0.5 \mathrm{~m} / \mathrm{s}$ & 困難 & 可能 & 可能 \\
\hline 不可能 & 氾濫危険度 3 可能 : 氾濫危険度 1 \\
困難 & $:$ 氾濫危険度 2
\end{tabular}

表 -5 氾濫流到達時間に基づく氾濫危険度指標

\begin{tabular}{c|c}
\hline 汇濫危険度 & 汇濫流の到達時間 \\
\hline 1 & 4 時間以上 \\
\hline 2 & 3 時間以上, 4 時間未満 \\
\hline 3 & 2 時間以上, 3 時間未満 \\
\hline 4 & 1 時間以上, 2 時間未満 \\
\hline 5 & 30 分以上, 1 時間未満 \\
\hline 6 & 0 分以上, 30 分未満 \\
\hline
\end{tabular}


であると考えられる。汇濫危険度を設定するに当 たっては, 家屋被害に影響を及ぼす汇濫流速や浸水 深を考慮すべきと考えられる。松富ら ${ }^{9}$ は，津波氾 濫流による家屋被害に関して, 過去の事例を対象と した調査を行い, 浸水深, 流速, 家屋被害の関係を 示している. また, 現地調查データに基づき, 浸水 深と流速, 浸水深と抗力の暫定的な関係式を決定し ている. 関係式と, 浸水深と家屋の造り別の被害程 度の関係から，家屋が破壊に至る流速は表-6のよう に示される。本研究では, 表-6に示す流速を用いて 家屋被害に基づく氾濫危険度指標を表-7のように設 定した.

\section{f）車・コンテナの流出に基づく氾濫危険度指標}

図-8に，紀の川流域委員会 ${ }^{10)}$ がまとめた氾濫によ る車への被害発生状況を示寸，車高にもよるが，お およそ浸水深が $1 \mathrm{~m}$ ぼに達すると, 車が汇濫水に 押し流されるとされている。

コンテナは通常, 積夕重㸚られて保管されており, ここでは，三段積みの場合を対象とした。ゼロメー トル地帯の高潮対策検討会 ${ }^{11}$ によると, 三段積みの コンテナに対し, 浸水深が $60 \mathrm{~cm}$ に達すると, コン テナが流出するとされている。よって，60 $\mathrm{cm}$ を境 に汇濫危険度のランク分けを行う．以上のことから，

表-6 家屋が破壊に至る流速 $(\mathrm{m} / \mathrm{s})^{9)}$

\begin{tabular}{|c|c|c|c|}
\hline 家屋の種類 被害程度 & 小破 & 中破 & 大破 \\
\hline 木造 & 1.6 & 3.5 & 4.2 \\
\hline コンクリート・ブロック造 & 2.6 & 5.2 & 10.2 \\
\hline 鉄筋コンクリート造 & 2.6 & 10.2 以上 & 10.2 以上 \\
\hline
\end{tabular}

表-7 家屋被害に基づく氾濫危険度指標

\begin{tabular}{c|c|c}
\hline $\begin{array}{c}\text { 氾濫 } \\
\text { 危險度 }\end{array}$ & 流速 & 家屋への被害 \\
\hline 1 & $1.6 \mathrm{~m} / \mathrm{s}$ 未満 & 被害はほぼなし \\
\hline 2 & $1.6 \mathrm{~m} / \mathrm{s}$ 以上, $2.6 \mathrm{~m} / \mathrm{s}$ 未満 & 木造家屋が小破 \\
\hline 3 & $2.6 \mathrm{~m} / \mathrm{s}$ 以上, $3.5 \mathrm{~m} / \mathrm{s}$ 未満 & $\begin{array}{c}\text { コンクリト・ブ } \\
\text { ロック造が小破 }\end{array}$ \\
\hline 4 & $3.5 \mathrm{~m} / \mathrm{s}$ 以上, $4.2 \mathrm{~m} / \mathrm{s}$ 未満 & 木造が中破 \\
\hline 5 & $4.2 \mathrm{~m} / \mathrm{s}$ 以上, $5.2 \mathrm{~m} / \mathrm{s}$ 未満 & 木造が大破 \\
\hline 6 & $5.2 \mathrm{~m} / \mathrm{s}$ 以上, $10.2 \mathrm{~m} / \mathrm{s}$ 未満 & $\begin{array}{c}\text { コンクリート・ブ } \\
\text { ロック造が中破 }\end{array}$ \\
\hline
\end{tabular}

車の被害発生状況

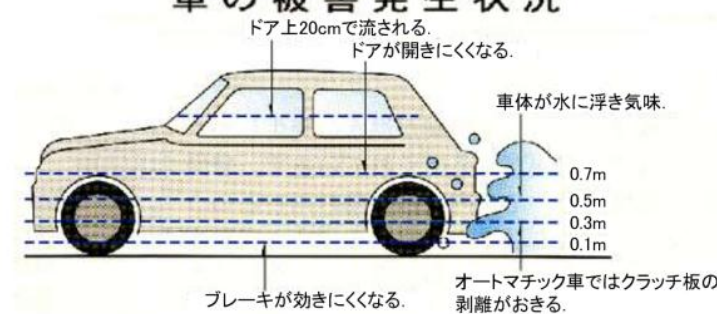

図-8 浸水による車への被害発生状況図 ${ }^{10)}$

\begin{tabular}{c|c|c} 
表-8 & \multicolumn{1}{c}{ 車・コンテナの流出に基づく氾濫危険度指標 } \\
\hline $\begin{array}{c}\text { 氾濫 } \\
\text { 危険度 }\end{array}$ & 浸水深 & 流出の危険性 \\
\hline 1 & $0.6 \mathrm{~m}$ 未満 & 車, コンテナともに流出の危険性なし \\
\hline 2 & $0.6 \mathrm{~m} ~ 1.0 \mathrm{~m}$ & 車の一部, コンテナに流出の危険性 \\
\hline 3 & $1.0 \mathrm{~m}$ 以上 & 車, コンテナともに流出する \\
\hline
\end{tabular}

車・コンテナの流出に基づく氾濫危険度指標を，表 -8のように設定した.

\section{（2）各指標に対する汇濫危険度の評価}

前節に示した6つの氾濫危険度指標を用いて，仮 想大型台風による高潮・高波氾濫シミュレーション の結果に対し，それぞれ氾濫危険度評価を行った。 ここでは，紙面の都合上，氾濫流速および汇濫流到 達時間を指標とした汇濫危険度を, 図-9および図一 10にそれぞれ示す。両図において，長島輪中周辺

（図-6参照）に着目すると，氾濫流速を指標とした 氾濫危険度では危険度 3 と高いものの, 氾濫流到達 時間を指標とした汇濫危険度では危険度2 と低いこ とがわかる。このように，多面的に氾濫危険度を評 価した場合, 各指標の結果に違いが生じることがあ り, どの地域がより危険であるかが，不明瞭となる ことがわかる。よって，種々の指標を総括して検討 し, 総合的に氾濫危険度を評価する必要があるとい える. また, 複数の指標を統合して汇濫危険度を設 定することで，簡易的ではあるものの，より信頼性 の高い氾濫危険度の総合評価を行うことが可能とな ると考えられる。

（3）高潮・高波による総合汇濫危険度の評価 a）総合汇濫危険度の設定

本研究では，式(1)に示すように，上記の6つの氾 濫危険度を用いて総合氾濫危険度を定義した。
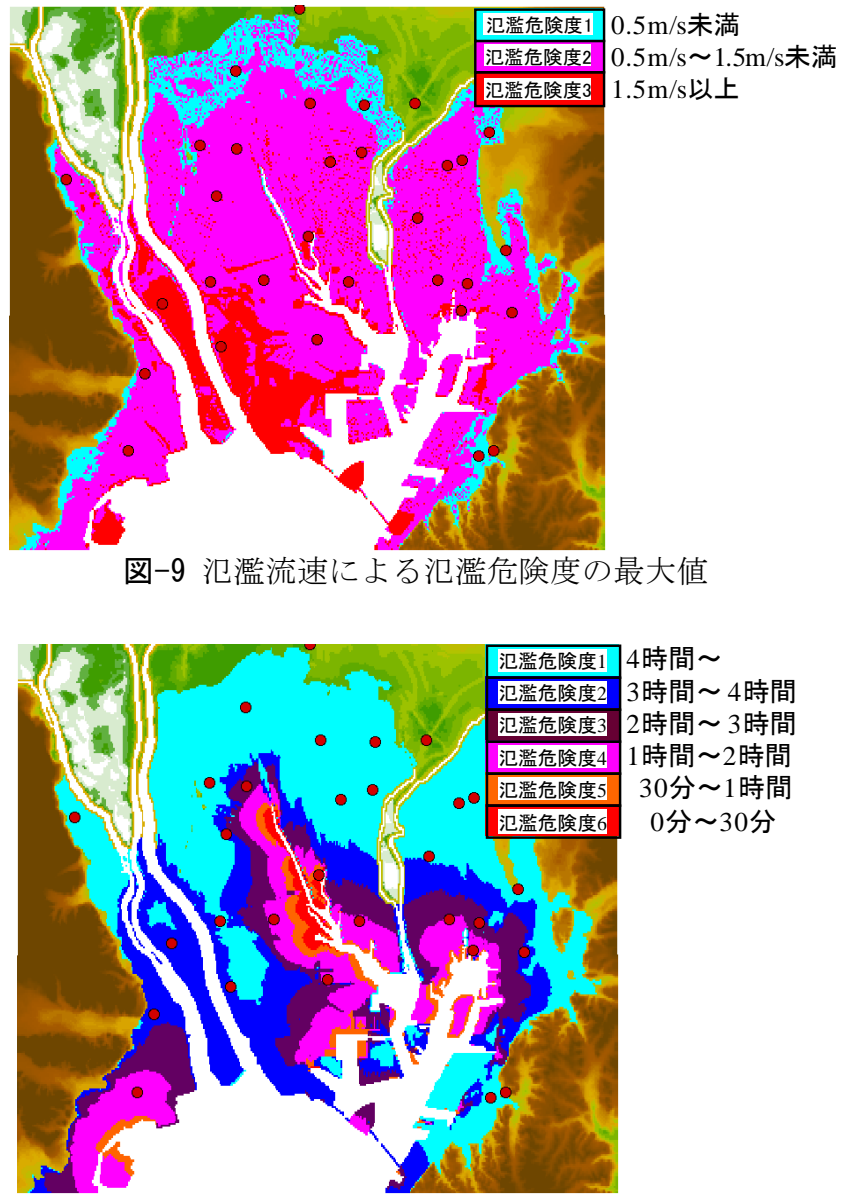

図-10 氾濫流到達時間による氾濫危険度の最大值 


$$
R_{c}=\sum_{i=1}^{6} \frac{R_{i}}{R_{\max i}} \times w_{i}
$$

ここで， $R_{c}$ は総合氾濫危険度， $R_{i}$ は各指標による氾 濫危険度， $R_{\max i}$ は各指標による汇濫危険度の最大 值， $w_{i}$ は各指標の総合汇濫危険度に対する重みであ る。重み $w_{i}$ は, 各地域の土地利用形態などを加味し, それぞれの指標に重みを付けて検討する必要がある. しかし, 本計算では, 重みを決定する情報が十分で はないため, 各指標に同等の重みをつけることとし, $w_{i}$ に $1 / 6$ をえた。 以上のように, 総合氾濫危険值 を計算し，表-9に示すように，湾奥部において危険 度のランクを設定した。

表 -9 総合氾濫危険度

\begin{tabular}{|c|c|}
\hline 危険度 & 総合汇濫危険度 $R_{c}$ \\
\hline 1 & $0 \sim 0.2$ \\
\hline 2 & $0.2 \sim 0.4$ \\
\hline 3 & $0.4 \sim 0.6$ \\
\hline 4 & $0.6 \sim 0.8$ \\
\hline 5 & $0.8 \sim 1.0$ \\
\hline
\end{tabular}

\section{b）氾濫危険度の総合評価}

総合的な危険度の最大值を図-11に示す。汇濫域 のほぼ全域で危険度3以上を示しており，湾奥部が 高潮・高波汇濫に対して非常に危険な地域であるこ とがよくわかる．特にゼロメートル地帯では，危険 度が4を示しており, 長島輪中中央付近では危険度 が5に達している。この付近は，ほぼ住宅のない自 然裸地となっており, 氾濫流の流れを妨げる障害物 がないため, 氾濫流の流速が非常に速くなったと推 測される. その結果, 住宅のある他の地域に比べて, 危険度が高くなったと考えられる。

\section{6. おわりに}

本研究では, 将来発生しうる超大型台風が伊勢湾 に来襲した場合を想定し, 高潮・高波氾濫シミュ レーションを行った. その結果, 伊勢湾台風と同等 の大規模な汇濫が生じることが判明した.さらに, 伊勢湾湾奥部における高潮氾濫状況に対して, 高 潮・高波による汇濫危険度指標として, 浸水深, 汇 濫流速, 汇濫流到達時間などの各指標を提案・議論 し, 伊勢湾湾奥部の高潮・高波氾濫に対寸る危険度 の総合的評価を行った。 総合的評価より, 特にゼロ メートル地帯を中心として伊勢湾湾奥部は非常に危 険性の高い地域であることが判明した。このように， 本評価システムは, 今後の高潮・高波氾濫による防 災・減災対策に役立つものといえる。ただし, 各指 標の総合的汇濫危険度に対寸る重みづけを本検討で は行っておらず，各地域の土地利用形態など様々な 情報を基に，それぞれの指標の重みを決定すること

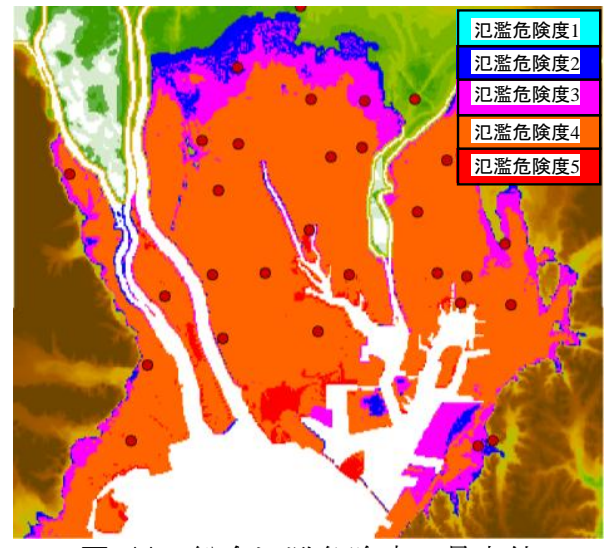

図-11 総合汇濫危険度の最大值

は今後の課題である.

謝辞 : 本研究の一部は, 科学研究費補助金・若手研 究(A) (研究代表者: 名古屋大学・ 川崎浩司, 課題 番号：21686046）であることをここに付記し，感謝 の意を表する. また, 本論文の執筆にあたり, 名古 屋大学大学院工学研究科博士課程前期課程 2 年生 鈴木一輝君に協力を頂いた。ここに謝意を表する.

\section{参考文献}

1) 吉野純, 小林孝輔, 児島弘展, 安田孝志: 大気・海 洋力学的手法に基づく伊勢湾の可能最大高潮 - 波浪 の評価, 土木学会論文集 B2 (海岸工学) , Vol.B2-65, No.1, pp.396-400, 2009.

2) 川崎浩司, 丹羽竜也, 水谷法美：高波の影響を考慮 した高潮・高波氾濫モデルの構築とその精度検証, 土木学会論文集 B2（海岸工学）, Vol.66 No.1, pp.196-200, 2010.

3) Yabe, T. and T. Aoki : Universal solver for hyperbolic equations by cubic-polynominal interpolation I. onedimensional solver, Computer Physics Communications, Vol.66, pp.219-232, 1991.

4) 小谷美佐, 今村文彦, 首藤伸夫：GIS を利用した津波 遡上計算と被害推定法, 海岸工学論文集, 第 45 巻, pp.356-360, 1998.

5) 国土交通省河川局治水課：浸水想定区域図作成又 ニュアル 平成 17 年 6 月, pp. 17, 2005.

6）建設省河川局治水課：洪水ハザードマップ作成要領 解説と運用改訂版 平成 12 年 9 月, 2000 .

7) 国土交通省河川局：地下空間における浸水対策ガイ ドライン 同 解説〈技術資料〉, pp.G-11，2001.

8) 末次忠司: 汇濫原管理のための氾濫解析手法の精度 向上と応用に関寸る研究, 九州大学諾意請求論文, 1998.

9）松富英夫, 首藤伸夫 : 津波の浸水深, 流速と家屋被 害, 海岸工学論文集, 第 41 巻, pp.246-250, 1994.

10) 紀の川流域委員会 : 洪水避難時の流速と水深につい て洪水解析モデルの違いについて, http://www.kkr.mlit. go.jp/wakayama/ryuiki_iinkai/ryuiki/comm11/pdf/data1_1 1.pdf, 2002.

11) 国土交通省：ゼロメートル地帯の高潮対策検討会, 第 2 回検討会（平成 17 年 11 月 14 日）会場追加 資料 コンテナ参考資料， 2005. 